\title{
Dynamics in higher education politics: a theoretical model
}

\author{
Kauko, Jaakko
}

2013

Kauko , J 2013 , ' Dynamics in higher education politics: a theoretical model ', Higher

Education , vol. 65 , no. 2 , pp. 193-206 . https://doi.org/10.1007/s10734-012-9538-z

http://hdl.handle.net/10138/42474

https://doi.org/10.1007/s10734-012-9538-z

submittedVersion

Downloaded from Helda, University of Helsinki institutional repository.

This is an electronic reprint of the original article.

This reprint may differ from the original in pagination and typographic detail.

Please cite the original version. 
This is a pre-print version of an article published in Higher Education and is not meant for quoting. The article Dynamics in Higher Education Politics - a Theoretical Model is available at http://www.springerlink.com/content/htk2813401483306/. Please use the final version for quoting. (DOI: 10.1007/s10734-012-9538-z.)

\title{
Dynamics in Higher Education Politics - a Theoretical Model
}

\author{
Jaakko Kauko \\ Behavioural Sciences, University of Helsinki

\section{P.O. Box 9 (Siltavuorenpenger 3 A) \\ FI-00014 University of Helsinki} \\ $+358919144420$ \\ jaakko.kauko@helsinki.fi \\ http://www.helsinki.fi/kupoli
}

New Politics and Governance in Education (KUPOLI) research unit, Institute of

This article presents a model for analysing dynamics in higher education politics (DHEP). Theoretically the model draws on the conceptual history of political contingency, agenda-setting theories and previous research on higher education dynamics. According to the model, sociohistorical complexity can best be analysed along two dimensions: the political situation and political possibilities. Politics as a situation connotes the idea of an opportune moment when politics can be changed, and political possibilities concern the different alternatives the actors see in different situations. Depending on whether the situation is favourable or unfavourable to change, and on whether the possibilities are politicised or settled, the DHEP model introduces four types of dynamic: reform, gridlock, consensual change and friction. On the empirical level the model has been tested and developed in the context of Finnish higher education by means of interviews and documentary material. It was found, in the Finnish context, that four policy threads functioned according to each of the dynamics. It appears from the empirical findings that dynamics in higher education politics are strongly related to changes that are external to the higher education political system, the changing positions of the actors in different policy threads and the unexpected nature of the dynamics. The DHEP can also be used to shed light on the effects of the silent, settled possibilities that may enable or disable other policy threads within a higher education system.

Dynamics, Higher Education Politics, Contingency, Agenda setting 


\section{Introduction}

Earlier research on higher education recognises the lack of theorising about the larger political whole and the tendency to focus on a single policy (Metcalfe 2008; Slaughter \& Rhoades 2005; c.f. Baumgartner, Green-Pedersen \& Jones 2006). Moreover, the approaches are rather polarised. A review of three influential higher-education journals reveals the dominance of a more or less descriptive and heuristic structural approach, whereas the actor, agency and other perspectives remain somewhat in the shadows (Ursin \& Saarinen 2012). An obvious source of new theories would be political science, but it features surprisingly seldom (Ferlie, Musselin \& Andresani 2008). It would thus seem to be an opportune moment for opening up new avenues for research. In this article I sketch a model for analysing dynamics in higher education politics (DHEP) that draws on previous research on political science and dynamics in this field.

The main focus in DHEP is on attributes of relations rather than of actors. This emphasis on interrelations or dynamics is not a common approach. Much of the research in the social sciences, and thus also on higher-education systems, starts from an analysis of the interests or distinct features of different actors. These are established and informative focal points, but from the perspective of interrelations they embed a presupposition of relatively stable characteristics in different subjects (Emirbayer 1997) and a static view of politics (Palonen 2007). Many scholars in higher education are aware of this problem. To put it in more practical terms, institutions in the higher-education system have varying significance in different reforms, and there are varying views on their importance (Olsen 2007; Välimaa 2005). There is a plethora of stories related to single-policy processes, and "different groups make sense of policy in different ways" (Mills 2007, 185). Ultimately, and paradoxically in terms of interests, policy makers may make dissonant decisions in different contexts (Kauko 2011). For this reason, focusing on dynamics could foster a deeper understanding of the complexity of the world.

Some of the basic research in the field of higher education is dual-focused on the attributes of both actors and relations. For instance, common to Clark's triangle and its earlier (e.g., Neave 1992; Frackmann 1992) and more recent (e.g., de Boer, Enders \& Schimanck 2007) additions is the idea of selecting key stakeholders 
(e.g., academia, the state or students) or operational logics (market or managerial) and comparing them in order to produce an empirically derived description of the higher-education system. However, critics such as Ferlie et al. $(2008,330)$ point out that Clark's focus on the state-university relationship ignores many other institutions, whereas Kogan and Hanney $(2000,26)$ question the presupposition that the special nature of universities defines the rest of the system (c.f. Frackmann 1992, 14). In other words, too often the research ideas direct us to take universities and their interests as a benchmark for the whole system.

The focus on universities also causes a problem with interest definition. For instance, Olsen (2007) makes a distinction based on whether a university is governed by internal or environmental factors, and whether the actors have shared or conflicting norms and objectives (c.f. Saarinen \& Välimaa 2006; Saarinen 2007). Any division between internal and external agendas would need a definition of the interests of the university and its stakeholders. The discussion on internal and external governance also easily reflects the dichotomy inherent in top-down and bottom-up models (see Cerych \& Sabatier 1986, 254-256; Sabatier 2005). Cerych and Sabatier $(1986,254)$, for instance, ran into the problem of complexity when adopting this perspective in their analysis of reforms and their success or failure. Drawing attention to interaction and its outcomes instead could avoid the uncomfortable question of interests. Furthermore, an equal focus on all institutions in the higher-education system could offer a welcome broader perspective.

Taking into account the criticism of earlier research, the DHEP model focuses on different institutions in a higher-education system and their relations. Institutions are assumed to control the behaviour of the people inside them through formal regulations, social norms or interpretations of reality, depending on the research tradition (Scott 2008, 47-80). They are also defined in a broad sense, as actors in themselves, and as encompassing political institutions, ministries, universities, labour unions, research funders and also, which is more unorthodox, university stakeholders such as interest organisations (c.f. Mayntz \& Scharpf 1995, 47-49). The model represents a macro-level approach in depicting institutions as the main actors inside a higher-education system, but also takes into account the policy 
entrepreneurs who are individual actors. In the following I describe the model, drawing on theories of political science, and trial it empirically in the context of Finnish higher education.

\section{Theorising dynamics in the context of contingency}

Although there has been research on dynamics in higher education, there is as yet no theoretical backbone facilitating their analysis. This motivated my interest in developing a model for analysing the dynamics in higher education politics (DHEP). Before diving into the research I should clarify two points on the formation of the model.

Firstly, the terms framework, theory and model are sometimes used interchangeably, but in this article I follow Ostrom (2005, 27-28), who understands them as being nested: a framework loosely identifies the essential elements of the research, the theory focuses this view and the theoretical model helps in making more precise assumptions. I will build the DHEP theoretical framework drawing on the conceptual history of political contingency and earlier research on dynamics in higher education. It will then be possible to focus on two dimensions of contingency. The theories further focusing the perspective relate to agenda setting, and are especially helpful in drawing out further interpretations of the two dimensions. Eventually, when connected with the empirical results, the theoretical insights made it possible to build a more precise model.

Secondly, in practice empirical and theoretical efforts have advanced side-by-side and the process has been far from linear. In building the theoretical model I draw on the empirical and theoretical work carried out in conjunction with a research project in the context of higher education politics in Finland (Kauko 2011). I conducted $^{1}$ and analysed 25 interviews with minister-level politicians, highly ranked ministry officers, university rectors and various stakeholder representatives (e.g., interest groups, labour unions and research funders), and analysed a corpus of 132 documents. The empirical and theoretical work advanced simultaneously, but this article focuses mainly on the theoretical

\footnotetext{
${ }^{1}$ Hannu Simola and/or Risto Rinne were also co-conducting the interviews.
} 
aspects. For the sake of clarity, in the following I will first present the theoretical model and only then deal with the empirical results.

Earlier research on dynamics in higher education focuses on the whole picture comprising the relations among institutions in their temporal and societal frames (Ferlie et al. 2008, 327; Gornitzka, Maassen, Olsen \& Stensaker 2007, 181-183; Meister-Scheytt \& Scheytt 2005; Bleiklie 2000, 54-55). These studies have two things in common. Firstly, there is a strong historical emphasis with an empirical basis. The institutions and actors in higher-education systems are bounded by history. It is virtually impossible to conduct an analysis in a complex situation without understanding the historical developments, and only an historical perspective gives access to the dynamics (Clark 2008, 401-402; Pierson 2004, 616; Bleiklie 2000, 71; 2006, 55; Kogan, Bauer, Bleiklie \& Henkel 2000, 208; see Corbett 2005; Scharpf 1997, 27-29). Secondly, the studies do not subscribe to the dominance of either agency or structure, but focus on interaction. On the agency side they emphasise the regularities and irregularities in the complexity of interrelations among institutions and actors. However, the structure also matters in that changes in the higher-education system are usually initiated by external impulses (Ferlie et al. 2008; Kogan et al. 2000, 213; see also Mayntz \& Scharpf 1995, 45). In sum, one could say that politics is always marked by contingency. This also forms the basis on which the DHEP theoretical framework was built.

In more practical terms, according to the dynamics approach, the contingency inherent in politics ensures that a policy reform will always differ from its original purpose - it is bound to fail. Policy is held hostage to a combination of political, economic and social factors, which make it impossible to believe in predetermined policy making (Bleiklie, Høstaker \& Vabø 2000, 286-307; see Välimaa \& Hoffman 2008).

In order to explain even more clearly what is meant by contingency I will refer to Palonen's (2006) vast history project in which he distinguishes three conceptual clusters on the theme of 'politics': prudence and policy, commitment and contestation, and contingency. Obviously the most interesting from the perspective of this paper is the contingency cluster, with its situation, possibility 
and play \& game dimensions. I will concentrate on the first two, and leave the third for further analysis: play \& game has more to do with concrete politicking, which takes the focus to the individual level, whereas my focus is on institutions. On the institutional level the game metaphor could be connected to game theory (Scharpf 1997), but this would require the best outcomes for each party involved to be defined, which could once again lead to the problem of defining interests. Hence, in forming the theoretical framework I suggest that, on the system level, dynamics in higher education politics is best analysed along these two dimensions: the political situation and political possibilities.

The two above-mentioned dimensions and the four types of dynamics they enable are described in the DHEP model depicted in Table 1. In line with the dynamics approach, the political situation ties the analysis to the historical context, whereas political possibilities bring out the interrelations among the institutions. I will now draw on agenda-setting theories in order to focus more closely on these two dimensions and the four dynamics.

Table 1. A theoretical model for analysing dynamics in higher education politics (DHEP) (Kauko 2011, Table 3)

\begin{tabular}{|l|c|c|}
\hline & $\begin{array}{l}\text { The political situation } \\
\text { unfavourable to change }\end{array}$ & $\begin{array}{l}\text { The political situation is } \\
\text { favourable to dhange }\end{array}$ \\
\hline $\begin{array}{l}\text { The political possibilities are } \\
\text { settled }\end{array}$ & Friction dynamics & Consensual change dynamics \\
\hline $\begin{array}{l}\text { The political possibilities are } \\
\text { politicised }\end{array}$ & Gridlock dynamics & Reform dynamics \\
\hline
\end{tabular}

\section{Favourable and unfavourable political situations}

Politics as a situation connotes the idea of an opportune moment, or kairos, when politics can be changed and when a historical rupture is visible. In order to make a change the actors have to notice the kairos, or make a radical re-interpretation in order to form such a moment (Palonen 2006; see Greek Anthology [1918] XVI, 275). I have noticed that many agenda-setting theories emphasising history recognise the opportune moment when the internal factors of a higher-education system are in line with the external factors. In order to make this more concrete I will scrutinise it in terms of three different theories: Sabatier's (1987) Advocacy Coalition Framework (ACF), punctuated equilibrium as advocated by Baumgartner and Jones (2009), and the match model (my naming) developed by Richardson, Bracco, Callan and Finney (1999). According to my synthesis, these 
agenda-setting theories divide the levels of operation into at least three separate spheres: external socio-historical developments, and the political system and subsystem.

The external factors have a lot to do with the socio-historical context, such as demographical trajectories (Richardson et al. 1999, 196) and the "changing contexts of policymaking" over time (Baumgartner \& Jones 2009, 54). Sabatier (1993) makes a more precise distinction between external stable factors (e.g., natural resources, and ethical and socio-cultural values) and changing events (e.g., public opinion). In terms of DHEP, the external factors relate to developments in the longue durée of history, which are mostly out of reach for the actors.

Both Baumgartner and Jones (2009) and Sabatier (1993) distinguish between a political subsystem, such as higher education, and the political system. Baumgartner and Jones (2009) understand the political system to be seemingly stable, but changing rather rapidly in certain periods of time. Richardson et al. (1999) see it as part of the "policy environment", and the subsystem as being described by the "system design". Generally speaking, a subsystem focuses on one policy issue, and I use it as a synonym for the higher-education system, in other words all the institutions focusing on the politics of higher education. In the DHEP model I make a distinction between the higher-education system and the political system. In the Finnish case the latter includes all the institutions in the Finnish polity and is considered part of the external factors of the former, which again includes the institutions involved in higher education decision-making.

The three agenda-setting theories have rather similar approaches to the change inside a subsystem, the key being in the relationship between institutional changes and external conditions. From a subsystem perspective, according to Sabatier, the opportune moment may be a reaction to external changes, or then a result of changes in the institutional structure of the higher-education system (Sabatier 1987; 1993). According to punctuated equilibrium theory, the relative importance of institutions changes in the long term. Institutions affect the scope of the agendas in the political system (Baumgartner \& Jones 2009, 16). The key facilitator of change is the interaction between the subsystem and its external 
factors. According to Richardson et al. $(1999,200)$, the institutional structure can be brought into line with the external factors, but if this does not happen, change is almost impossible. Martinez $(2002,368)$ describes the match model thus: "if compatibility among and between the policy levels is absent, conflict, frustration, and gridlock result". Regarding the change in institutional structure, Sabatier also holds that the formation of coalitions inside the subsystem, in addition to changes outside it, can trigger change (Sabatier 1993, 24). To summarise the different views on constructing DHEP, the political situation for change is embedded in the institutional structure of the higher-education system and how it is aligned with the external factors. This also explains why changes in the institutional structure could indicate the birth or death of a kairos.

The different theories also give some guidance as to the forms the institutional structure can take. According to Baumgartner and Jones (2009, 32-36), institutions form policy venues where policy entrepreneurs can act. However, there may also be monopolies, created to delimit the contestation by emphasising the complexity, the required professionalism or social unimportance of an issue (Baumgartner \& Jones 2009, 6-7). Then again, Sabatier puts forward the idea of creating coalitions of ideologically similar enough institutions (Sabatier 1993; Jenkins-Smith \& Sabatier 1993). In other words, the institutional structure also affects what can be politicised and what kinds of issues make it to the agenda.

The different agenda-setting theories have attracted criticism. Kingdon (2003, 226-227) claims that punctuated equilibrium focuses too much on balance, and that change dynamics would be a more important factor in explaining decisionmaking. Martinez (2002), in turn, criticises the match model for giving too few tools with which to consider how the different levels become matched. These are significant critiques, pointing out that the theories are rather focused on historical developments and leave the more concrete politics to one side. However, their contribution in terms of understanding the situational preconditions of change is vital for the development of a theoretical model of dynamics in higher education politics. 
In sum, the political situation is a result of interplay between the institutional framework of the higher-education system, the political system and the sociohistorical context. If the institutional framework within the education system is not compatible with the external factors, the political situation is unfavourable to change. In order to make the situation favourable the actors need either to change the institutional structure or to wait for the external factors to change. (Table 1)

\section{Politicised and settled possibilities}

Political possibilities concern the different alternatives the actors see and create in different situations. Possibilities for action are always present, but it is a question of active search and use (Palonen 2006, 237). The possibility dimension improves the theoretical model in taking into account the critique aimed at the situation dimension, and providing tools that enhance understanding of changing politics. Possibilities are created through politicisation, the re-interpretation of some issue as a conflict or the re-organisation of the conflicts at hand (Palonen 2003; 1993). Removing politicised possibilities, or depoliticising, is very difficult (see Palonen 1993). Within the agenda-setting theories, Kingdon's (2003) multiple streams model facilitates the analysis of politicisation. The key question is why some issues appear on the political agenda, and why some policies become respectable alternatives, whereas other issues and policies find their way into the dustbin of history. In analysing the formation of politicisation, multiple streams offer insights into how politicised possibilities are created that could benefit the DHEP model.

Thus, the agenda-setting process is explained in terms of three different streams: problems, politics and policies (Kingdon 2003). According to the approach, problems are created by different indicators reflecting the magnitude of a condition, 'focusing events' such as disasters or feedback indicating some problems in the system. When a problem is recognised it assumes the potential to reach the political agenda. Politics refers to changes in the national mood, government changes after elections, or changes in the distribution of seats in parliament, whereas policies deal with the alternatives. Expert communities and government officers contribute to the "policy primeval soup", a cornucopia of solutions. Different alternatives are then selected according to technical, ethical 
and fiscal criteria, as well as to the interests of the public and politicians. (Kingdon 2003, 197-201) Kingdon's core theoretical insight into changing the course of politics is the merging of the three streams, which is the work of policy entrepreneurs who try to connect two or more of them (Kingdon 2003, 202). If all three streams are connected, the issue will be fixed on the agenda, that is, politicised. One of Kingdon's (2003) inspired ideas is his non-linear approach to decision-making. In fact, more often policy entrepreneurs seek suitable problems for their pet proposals rather than alternatives that are invented only after politicisation has taken place (see Baumgartner \& Jones 2009, 19).

Kingdon's model is of vital help in understanding different forms of politicisation. However, according to various critics the multiple-streams approach lacks a strong historical dimension (Baumgartner \& Jones 2009, 5; Baumgartner et al. 2006, 963; Zahariadis 1999, 85). Kingdon (2003, 207) discusses the "general constraints of the system" and goes through some history in the context of a few policy cases. However, the focus is on the creation of new policy space rather than giving a consistent perspective on history. Other research points out the apparent interconnection between the historical formulation of institutions and politicisation, however. Baumgartner and Jones (2009), for instance, analyse the role of politicisation (policy images) in the re-formulation of the institutional structure. The critique supports the solution in DHEP to include both the historically-oriented-situation dimension and the possibility dimension.

In sum, I understand political possibilities through the concept of politicisation, but in the DHEP model they may be either settled or politicised (Table 1). Politicisation means that the actors find or create new possibilities, whereas settled possibilities refer to routine actions performed according to old practices.

\section{Analysing dynamics by means of a theoretical model}

Within the two dimensions of the political situation and political possibilities the theoretical model describes four different types of dynamics in education politics, as Table 1 shows. In order to put some empirical flesh onto the theoretical skeleton, I exemplify the dynamics through the case of Finnish higher education 
(Kauko 2011). As Table 2 indicates, inherent in the Finnish case are four independent policy threads, each illustrating one of the dynamics. A policy thread refers to the historical development of a policy inside higher education politics.

When I was conducting the analysis I first considered the documentary and interview material. As mentioned in connection with the theoretical framework, I focused on the relations between the institutions, and identified four central policy threads representing the major aspects in the dynamics. After re-analysing the research material in terms of the regularities and irregularities within the policy threads I was able to build a theoretical model leaning towards agenda-setting theories. Finally, in order to test my conclusions I searched for conflicting views in the research material and was able to finalise the interpretation.

Table 2. Dynamics in higher education politics and the Finnish policy threads (Kauko 2011)

\begin{tabular}{|l|l|l|}
\hline & $\begin{array}{l}\text { The political situation is } \\
\text { unfavourable to change }\end{array}$ & $\begin{array}{l}\text { The political situation is } \\
\text { favourableto change }\end{array}$ \\
\hline $\begin{array}{l}\text { The political possibilities are } \\
\text { settled }\end{array}$ & $\begin{array}{l}\text { Friction dynamics in the } \\
\text { governance policy thread }\end{array}$ & $\begin{array}{l}\text { Consensual change dynamics } \\
\text { in the international policy } \\
\text { thread }\end{array}$ \\
\hline $\begin{array}{l}\text { The political possibilities are } \\
\text { politicised }\end{array}$ & $\begin{array}{l}\text { Gridlock dynamics in the } \\
\text { regional-policy thread }\end{array}$ & $\begin{array}{l}\text { Reform dynamics in the } \\
\text { research policy thread }\end{array}$ \\
\hline
\end{tabular}

The first of the dynamics is reform, meaning that the political situation favours change, and that the politicised possibilities support it. The Finnish research policy thread functions according to this dynamic (Table 2, lower-right cell). The Finnish political situation has been very favourable to research-policy change with an emphasis on innovation. A long-term conceptual push for a national innovation system was responsible for most of the groundwork (see Miettinen 2002), and the idea was solidified as the system was considered the main reason for Finland's emergence from the economic depression of the 1990s.

"That whole period of time had - - [a feeling] after the depression of the 1990s that everything is possible now. Nokia [Corporation] started to rise, there were no limits. That is the general atmosphere how people felt." (Stakeholder) 
Changes in the institutional structure supported the further emphasis on innovations. The founding of the Finnish Funding Agency for Technology and Innovation in 1983 enhanced innovation-based funding. More recently the "superministry" in the form of the Ministry of Employment and Economy, established in 2008, took a visibly expansive role in innovation policy:

\footnotetext{
"It seems that there [in the Ministry of Employment and Economy] is an attempt to harness the whole education policy and science policy under the innovation policy - -." (Stakeholder.)
}

The interviewees also recognised two coalitions of institutions existing in the institutional structure: the innovation coalition and the basic research coalition. However, more politicised possibilities were created favouring innovation activities over basic research. This allowed the policy entrepreneurs to function in the field of innovation policy. A prime example, according to the interviewees, is the former Finnish Prime Minister Esko Aho, who led the drafting of a national innovation strategy in 2008. He had also worked on similar issues on the European level, and there were certain similarities in the suggested solutions (see European Commission 2006; Työ- ja elinkeinoministeriö 2008; Finnish Government 2009).

Secondly, gridlock dynamics happen when there are politicised possibilities but they prove futile because the political situation does not allow change (Table 2, lower-left cell). The combination of a political system based on provincial representation, a regional higher education institutional framework and international pressure to streamline the structure created an unfavourable political situation in Finnish higher education. Officers in different ministries had been politicising possibilities for decades in the so-called "regional development plan", the aim of which was to downsize the higher-education system (see Vanttaja \& Ketonen 1995; Ursin, Välimaa \& Aittola 2010; 2011). However, these efforts did not have much effect due to provincial pressure on politicians. 
"We officers had suggestions for changes and development, which were blocked by political opposition and thus have not advanced." (Officer)

"The idea that we would reduce university teaching [programmes], I do not see it as possible." (Politician)

Thirdly, in conditions of consensual change dynamics the political situation favours change, but without politicisation it happens in a routine manner (Table 2, upper-right cell). It was apparent in the Finnish research material that the international policy promoted consensual change. There was shared experience of a kairos based on "globalisation". Moreover, the institutional framework has been moulded to become more receptive to international influences. For instance, the Ministry of Education and Culture integrated international affairs into its everyday practices in the 1990s. However, the practical work is done by officials as part of their duties, and not so much by politicians, stakeholders, or even university rectors.

"The Ministry of Education [and Culture] has kept in very close touch with international trends. And many times these ideas and thoughts have arrived - - through the ministry." (Rector)

Ministry officers played a relevant part in international activities. However, their way of working conveyed a pragmatic national attitude, implying settled political possibilities. (Kauko 2011)

\begin{abstract}
"This kind of Finnish pragmatism carries the idea of "why are they talking about values and ideologies, this is a waste of time - shouldn't we get down to business and see what to do in practice'."
\end{abstract} (Officer)

The pragmatic and selective infiltration of international influences into national policy making had effects in all other policy threads examined as the abstract ideas of global competition served as a catalyst for politicisation. The research- 
policy reform was strongly affected by perceptions of the importance of innovation in strengthening national competitiveness. The regional policy thread was greatly affected by ideas taken from the OECD country review of 2006 (OECD 2009). Moreover, embedded in the governance policy thread, discussed below, were past politicisations drawing on international influences, such as New Public Management (NPM) from the mid-1980s. All in all, it seems that the international environment is a key policy primeval soup (Kingdon 2003), from which the policy entrepreneurs, in the Finnish case mostly officers, find their solutions to present in the national political arena.

The fourth type of dynamics is that of friction, which causes inertia as long as the situation is not favourable to change and there are no politicised possibilities (Table 2, upper-left cell). In the context of Finnish higher education this was evident in the governance policy. The political situation owes a lot to the NPM reforms. An unfavourable situation arose involving incompatibility between the political and the higher-education system when politico-strategic and budgetary decision-making were separated in the late 1980s (see Temmes 1996; 1998; Tiili 2008). For instance, budget decisions on the government level are made strictly in accordance with the sectorial borderlines between the different ministries, and moving funds over the boundary of any ministry is virtually impossible in the framework budget. Moreover, the budget is not coordinated with the Government Programme. One officer criticised this atomistic perspective:

"The drafting of the budget frame cannot start by reading the base paper page by page. We should first take a day to talk about it [as a whole]. And when we start on the chapter concerning the Ministry of Education [and Culture], we should first discuss what we want from education - - and not start with the numbers." (Officer)

The same situation applies to the conditional contracting between the Ministry of Education and Culture and the universities: both sides understand that the other's main interest is money, which leaves policy questions secondary in the management-by-results negotiations. In the interviews, the ministry representatives saw the universities as not being interested in policy, only in 
money, and the universities detected too much ministry focus on budgetary issues instead of policies:

"For instance, these common goals we thoroughly prepare here [in the Ministry of Education and Culture] - - the management of the universities have seldom anything to say." (Officer)

"But then they [the Ministry of Education and Culture] announced almost bluntly that these graduation goals [which are the basis for funding] are defined in a way that every university could survive. - No attention was paid to the level of research in a given area of education, or in a given university - -." (Rector)

The friction dynamics due to the separation of budgetary means and political ends in the governance policy thread restricts other policies. The gridlock in the regional-policy thread was even tighter. For instance, budgetary pressure to abolish regional units of universities was understood, but in terms of regional politics it was impossible to implement. There was a similar friction phenomenon in research policy, as the heavyweight policy-making body, the Research and Innovation Council, which is loaded with ministers, rarely had full financial backing from the government: "It makes decisions on where money should be channelled, which have sometimes materialised, sometimes not." (Politician) All in all, there were no opportunities for forming a holistic view because the budget and policy discussions did not go on around the same table at the same time.

Two monopolies helped the non-politicisation of the international and government policy threads. In the former case, the Ministry of Education was mainly responsible for filtering international trends through its connections with the OECD and the EU, whereas in the latter the Ministry of Finance had a monopoly in starting governance reforms, and also in making the first drafts of the budget frameworks.

It thus seems that the policy threads in the consensual change and friction dynamics influenced the whole system. On the one hand, the consensual change in 
international policy gave a boost to politicisations in the other policy threads. On the other hand, the friction in governance policy also stalled other threads. The empirical results would suggest that the things that are not spoken, that is not politicised, are actually the most influential.

\section{A new model for higher education research in contingent contexts}

Focusing on the interrelations between institutions seemed to give a good base for DHEP and the empirical example of Finland. The Finnish case supported the presuppositions of earlier research on dynamics. It seems from the findings that dynamics in higher education politics are strongly related to changes that are external to the higher-education political system, the changing positions of the institutions or actors in the different policy threads, and the unexpected nature of the dynamics.

Earlier research identified the external factors of a higher-education system as one of the main reasons for change (see Kogan et al. 2000; Richardson et al. 1999; Sabatier 1993). However, the theoretical dimension of the political situation could facilitate a more accurate conceptualisation of this change. A favourable situation needs at least three aspects to be coherent: the major trajectories in history, in other words the socio-historical context; the political system, which has to allow change; and the institutional structure of the higher-education system, which has to be receptive to change. According to the DHEP model, changes in each of these may stimulate or undermine a favourable political situation, a kairos. In addition, the course of change is determined in terms of either settled or politicised possibilities.

Treating universities similarly as other institutions in the analysis seemed fruitful, as suggested in earlier research (see Saarinen \& Välimaa 2006; Ferlie et al. 2008; Frackmann 1992). I made no observations suggesting that the academic role of the universities could have affected any dynamics in the system. For instance, the most influential friction dynamics had nothing to do with academic characteristics. Not taking the uniqueness of universities as a starting point helped 
me to concentrate on multiple institutions, and to give a more holistic view on the Finnish higher education system.

Previous research focusing on dynamics ignores considerations of architectural politics and accepts the difference and fluidity in the positions of institutions (Olsen 2007; Välimaa 2005; Bleiklie et al. 2000). The DHEP model seemed promising in terms of understanding these changes in positions. The four different dynamics concerned the same institutions, but their roles were rather different. For example, whereas the Ministry of Education and Culture was the kingpin in the consensual relaying of international influences, it was powerless in the more controversial regional politics. This also implies criticism of the static view on politics, focusing on the attributes of actors: the same institutions vary in the weight they carry depending on the dynamics inside the policy thread.

The unexpected nature of politics is recognised in previous research on dynamics through the overarching idea of contingency. In analytical terms this means that the changes in the political situation and the politicisation of possibilities lead to an unexpected outcome. What has not been prominent so far is the analysis of the silent, restricting aspects of higher education politics. Välimaa (2005), for instance, examines different politicised and visible conflicts in the course of Finnish higher education. Most importantly, the DHEP model makes it possible also to get a grip on the effects of the settled possibilities that may enable or disable other policy threads.

From my perspective, there are three major projects aimed at the further development of DHEP: broadening it to include politicking, refining it for use in comparative education, and analysing dynamics in other areas of politics. Analysis of politicking could stem from the "play \& game" dimension of contingency (Palonen 2006), focusing on micro-level action based on ethnography or deep interviews. In terms of comparative research, DHEP has the potential to overcome the challenge of developing a more history- and society-conscious comparison (Kauko, Simola, Varjo \& Kalalahti 2012; Nóvoa \& Yariv-Mashal 2003). Broadening the model to other areas of politics could start with compulsory education: there are hints of similar dynamics in the Finnish case, for 
instance (see Simola, Varjo \& Rinne 2011; Simola, Rinne, Varjo, Pitkänen \& Kauko 2009). Nevertheless, the most interesting development would be to improve the model by discovering more dynamics. This will need more empirical work and remains a future research opportunity to be seized.

\section{Acknowledgements}

My research was part of the project Power, Supranational Regimes and New University Management, funded by the Academy of Finland project Power and Society (2007-2010). The project leaders were Risto Rinne (University of Turku) and Hannu Simola (University of Helsinki). I am grateful to them for their support during the dissertation process, and to the many colleagues and friends from whom I was fortunate enough to receive help (see Kauko 2011). I would also like to thank Wieland Wermke and the well-informed anonymous reviewers, who helped me to articulate and develop my ideas further in this article.

\section{References}

Baumgartner, F. R. \& Jones, B. D. (2009). Agendas and instability in American politics. 2nd ed.

Chicago, IL: Chicago University Press.

Baumgartner, F. R., Green-Pedersen, C. \& Jones, B. D. (2006). Comparative studies of policy agendas. Journal of European Public Policy, 13 (7), 959-974.

Bleiklie, I. (2000). Policy Regimes and Policy Making. In M. Kogan, M. Bauer, I. Bleiklie, \& M. Henkel (Eds.) Transforming Higher Education. A Comparative Study (pp. 53-87). London: Jessica Kingsley.

Bleiklie, I., Høstaker, R. \& Vabø, A. (2000). Policy and Practice in Higher Education. Reforming Norwegian Universities. Higher Education Policy Series 49. London: Jessica Kingsley.

Boer, H. de, Enders, J. \& Schimanck, U. (2007). Comparing Higher Education Governance Systems in Four European Countries. In N. C. Soguel \& P. Jaccard (Eds.) Governance and Performance of Education Systems (pp. 35-54). Dordrecht: Springer.

Cerych, L. \& Sabatier, P. (1986). Great Expectations and Mixed Performance: The Implementation of Higher Education Reforms in Europe. Trentham: Trentham Books.

Clark, B. R. (2008). The Problem of Complexity in Modern Higher Education [Originally 1993].

In B. R. Clark, On Higher Education. Selected Writings, 1956-2006, 385-404. Baltimore, MD: The Johns Hopkins University Press.

Corbett, A. (2005). Universities and the Europe of Knowledge. Ideas, Institutions and Policy Entrepreneurship in European Union Higher Education Policy, 1955-2005. Basingstoke: Palgrave Macmillan. 
Emirbayer, M. (1997). Manifesto for a Relational Sociology. The American Journal of Sociology, 103 (2), 281-317.

European Commission (2006). Creating an Innovative Europe. Report of the Independent Expert Group on R\&D and Innovation appointed following the Hampton Court Summit and chaired by Mr. Esko Aho. January 2006. Luxembourg: Office for Official Publications of the European Communities. http://ec.europa.eu/invest-in-research/pdf/download_en/aho_report.pdf. Accessed 9 November 2011.

Ferlie, E., Musselin, C. \& Andresani, G. (2008). The steering of higher education systems: a public management perspective. Higher Education, 56 (3), 325-348.

Finnish Government (2009). Governments Communication on Finland's National Innovation Strategy to the Parliament.

http://www.tem.fi/files/21010/National_Innovation_Strategy_March_2009.pdf. Accessed 9 November 2011.

Frackmann, E. (1992). The Role of Buffer Institutions in Higher Education. Higher Education Policy, 5 (3), 14-17.

Gornizka, Å., Maassen, P., Olsen J. P. \& Stensaker, B. (2007). "Europe of Knowledge": Search for a New Pact. In P. Maassen \& J. P. Olsen (Eds.) University Dynamics and European Integration, 181-214. Dordrecht: Springer.

Greek Anthology V (1918). Eds. E. Capps, T. E. Page \& W. H. D. Rouse. New York, NY: G.P. Putnam's sons. http://www.archive.org/stream/greekanthology05newyuoft. Accessed 9 November 2011.

Jenkins-Smith, H. C. \& Sabatier, P. A. (1993). The Study of Public Policy Processes. In P. A. Sabatier \& H. C. Jenkins-Smith (Eds.) Policy Change and Learning. An Advocacy Coalition Approach (pp. 1-9). Boulder, CO: Westview Press.

Kauko, J. (2011). Korkeakoulupolitiikan dynamiikat Suomessa [Dynamics of Higher Education Politics in Finland]. Helsinki: University of Helsinki, Department of Behavioural Sciences. http://urn.fi/URN:ISBN:978-952-10-6984-0. Accessed 9 November 2011.

Kauko, J., Simola, H., Varjo, J. \& Kalalahti, M. (2012) What could a dynamics perspective contribute to comparative research? In J. Kivirauma, A. Jauhianen \& P. Seppänen (Eds.) [Title yet open]. Research in Educational Sciences. Helsinki: Finnish Educational Research Association. Kingdon, J. W. (2003). Agendas, Alternatives, and Public Policies. 2nd ed. New York: Longman. Kogan, M. \& Hanney, S. (2000). Reforming Higher Education. Higher Education Policy 50.

London: Jessica Kingsley.

Kogan, M., Bauer, M., Bleiklie, I. \& Henkel, M. (2000). Change and Continuity. Some

Conclusions. In M. Kogan \& S. Hanney (Eds.) Reforming Higher Education (pp. 199-214).

London: Jessica Kingsley.

Martinez, M. C. (2002). Understanding State Higher Education Systems. Applying a New Framework. The Journal of Higher Education, 73 (3), 349-374.

Mayntz, R. \& Scharpf, F. W. (1995). Der Ansatz des akteurzentrierten Institutionalismus [The actor-centred approach to institutionalism] In R. Mayntz \& F. W. Scharpf (Eds.) Gesellschaftliche 
Selbstregelung und politische Steuerung [Societal self-regulation and political steering], 39-72. Frankfurt a.M. \& New York, NY: Campus Verlag.

Miettinen, R. (2002). National Innovation System. Scientific Concept or Political Rhetoric.

Helsinki: Edita.

Meister-Scheytt, C. \& Scheytt, T. (2005). The Complexity of Change in Universities. Higher Education Quarterly, 59 (1), 76-99.

Metcalfe, A. S. (2008). Theorizing Research Policy: A Framework for Higher Education. In J. C. Smart (Ed.), Higher Education: Handbook of Theory and Research (pp. 241-275). Dordrecht: Springer.

Mills, M. R. (2007). Stories of Politics and Policy: Florida's Higher Education Governance Reorganization. The Journal of Higher Education, 78 (2), 162-187.

Neave, G. (1992). On Bodies vile and Bodies Beautiful: the Role of 'Buffer' Institutions Between Universities and State. Higher Education Policy, 5 (3), 10-17.

Nóvoa, A. \& Yariv-Mashal, T. (2003). Comparative Research in Education: a mode of governance or a historical journey? Comparative Education 39 (4), 423-439.

OECD (2009). OECD Reviews for Tertiary Education. Finland. [Written by John Davies, Thomas Weko, Lillemor Kim and Erik Thulstrup.] OECD.

Olsen, J. P. (2007). The Institutional Dynamics. In P. Maassen \& J.P. Olsen (Eds.) University Dynamics and European Integration, 25-34. Dordrecht: Springer.

Ostrom, E. (2005). Understanding Institutional Diversity. Princeton, NJ: Princeton University Press.

Palonen, K. (1993). Introduction: from policy and polity to politicking and politicization. In K. Palonen \& T. Parvikko (Eds.) Reading the Political: Exploring the Margins of Politics (pp. 6-16). Helsinki: The Finnish Political Science Association.

Palonen, K. (2003). Four Times of Politics: Policy, Polity, Politicking, and Politicization. Alternatives, 28 (2), 171-186.

Palonen, K. (2006). The Struggle with Time. A Conceptual History of 'Politics' as an Activity. Hamburg: Verlag Münster.

Palonen, K. (2007). Politics or the political? An historical perspective on a contemporary nondebate. European Political Science, 6 (1), 69-78.

Pierson, P. (2004). Politics in Time. History, Institutions, and Social Analysis. Princeton \& Oxford: Princeton University Press.

Richardson, R.C., Bracco, K. R., Callan, P. M. \& Finney, J. E. (1999). Designing State Higher Education Systems for a New Century. Phoenix, AZ: The Oryx Press.

Saarinen, T. (2007). Quality on the move. Jyväskylä studies in humanities 83. Jyväskylä:

University of Jyväskylä

Saarinen, T. \& Välimaa, J. (2006). Muutos korkeakoulupolitiikan tutkimuksessa. [Change in higher education studies.] In J. Ursin \& J. Välimaa (Eds.) Korkeakoulutus teoriassa [Higher education in theory] (pp. 91-111). Jyväskylä: Koulutuksen tutkimuslaitos, Jyväskylän yliopisto. Sabatier, P. A. (1987). Knowledge, Policy-Oriented Learning, and Policy Change. An Advocacy Coalition Framework. Knowledge: Creation, Diffusion, Utilization, 8 (4), 649-692. 
Sabatier, P. A. (1993). Policy Change over a Decade or More. In P. A. Sabatier \& H. C. JenkinsSmith (Eds.) Policy Change and Learning. An Advocacy Coalition Approach (pp. 13-39).

Boulder, CO: Westview Press.

Sabatier, P. A. (2005). From Policy Implementation to Policy Change: A Personal Odyssey. In Å. Gornitzka, Å., Kogan, M. \& Amaral, A. (eds.), Reform and Change in Higher Education (pp. 1734). Dordrecht: Springer.

Scott, R. W. (2008). Institutions and Organizations. 3rd ed. Thousand Oaks, CA: Sage.

Simola, H., Rinne, R., Varjo, J., Pitkänen, H. \& Kauko, J. (2009). Quality assurance and evaluation (QAE) in Finnish compulsory schooling: a national model or just unintended effects of radical decentralisation? Journal of Education Policy, 24 (2), 163-178.

Simola, H., Varjo, J \& Rinne, R. (2011) À contre-courant: dépendance au sentier, convergence et contingence. Vers une meilleure compréhension du modèle finlandais d'assurance-qualité et d'évaluation. [Against the Flow - Path dependence, convergence and contingency in understanding the Finnish QAE model]. Éducation et Sociétés: Revue internationale de sociologie de l'éducation, 28 (2), 35-51

Slaughter, S. \& Rhoades, G. (2005). From "Endless Frontier” to "Basic Science for Use": Social Contracts between Science and Society. Science, Technology \& Human Values, 30 (4), 536-572. Temmes, M. (1996). Hallintopolitiikan rakennedoktriinit [The structural doctrines in governance policy]. Hallinnon tutkimus, 15 (2), 90-109.

Temmes, M. (1998). Finland and New Public Management. International Review of Administrative Sciences, 64 (3), 441-456.

Tiili, M. (2008). Ministers as strategic political leaders? Strategic political steering after NPM reforms in Finland. Acta Politica 34. Helsinki: Department of Political Science, University of Helsinki.

Työ- ja elinkeinoministeriö (2008). Kansallinen innovaatiostrategia. Helsinki: Työ- ja elinkeinoministeriö.

Ursin, J. \& Saarinen, T. (2012). Dominant and emerging approaches in the study of higher education policy change. Studies in Higher Education 37, (3). [Forthcoming in May 2012] Ursin, J., Välimaa, J. \& Aittola, H. (2010). Towards Joint Educational Structures and Practices. Experiences From The Mergers of Finnish Universities. Paper presented in the EERA-conference, 25.8.2010, Helsinki.

Ursin, J., Välimaa, J. \& Aittola, H. (2011). Yliopistot yhdistyvät - muuttuuko koulutus? In R. Rinne, A. Jauhiainen, J. Tähtinen ja M. Broberg (Eds.) Koulutuspolitiikan käytännöt kansallisessa ja ylikansallisessa kehyksessä, 125-144. Kasvatusalan tutkimuksia 54. Turku: Suomen kasvatustieteellinen seura.

Välimaa, J. \& Hoffman, D. (2008). Knowledge society discourse and higher education. Higher Education, 56, 265-285.

Välimaa, J. (2005). Social Dynamics of Higher Education Reforms: The Case of Finland. In A. Gornitzka, M. Kogan \& A. Amaral (Eds.), Reform and Change in Higher Education. Analysing Policy Implementation (pp. 245-268). Dordrecht: Springer. 
Vandenberghe, F. (1999). "The Real is Relational": An Epistemological analysis of Pierre Bourdieu's Generative Structuralism. Sociological Theory, 17 (1), 32-67.

Zahariadis, N. (1999). Ambiguity, Time, and Multiple Streams. In P. A. Sabatier (Ed.) Theories of the Policy Process, 73-93. Boulder, CO: Westview Press. 